\title{
Local Wisdom Values of Maritime Community in Preserving Marine Resources in Indonesia
}

\author{
Sem Touwe \\ History Education Study Program, Faculty of Teacher Training and Education, \\ Pattimura University, Ambon, Maluku, Indonesia
}

DOI: https://doi.org/10.14710/jmsni.v4i2.4812

\begin{abstract}
This study identifies and describes the local wisdom carried out by the coastal communities, especially the people of North Seram, Maluku in preserving the island and marine environment as well as the customary institutions in determining and guarding local wisdom of coastal communities to manage marine resources. The marine resource is started to weaken along with the development of modern technology. This paper provides contemporary phenomena regarding the weakness of customary laws and traditional institutions that regulate marine resources, including social values in the form of rituals, representing the relationship between humans and their environment. The protection of marine resources around them will be an

Received:

May 1, 2020

Revised:

December 23, 2020

Accepted:

December 25, 2020

${ }^{*}$ Corresponding Author:

drs.semt@yahoo.com important discussion to see the role of government and society in preserving marine and coastal resources. This study used a qualitative approach to produce descriptive explanations from reports, book reviews, and documents that describe theories and information of both past and present. The result is that the local wisdom maintained as superior cultural practices that are beneficial to human survival, especially in maintaining the sustainability and balance between humans and living objects.
\end{abstract}

Keywords: Local Wisdom; Coastal Area Resources; Local Institutions.

\section{Introduction}

The 1957 Juanda Declaration and UNCLOS 1982 designated Indonesia as an archipelago state with a huge maritime economic potential. As the largest archipelago state in the world, Indonesia has a total sea area of 5,8 million $\mathrm{km}^{2}$ comprising of territorial area of 3,2 million $\mathrm{km}^{2}$ and Indonesia Exclusive Economic Zone (ZEEI) of 2,7 million $\mathrm{km}^{2}$ (Sulistiyono 2017, 55). In addition, there are 17.840 islands in Indonesia with $90.000 \mathrm{~km}$ coastline. Moreover, there is a total of 22,000 species of fish which inhabit our planet; it is estimated that most of them are found in the Indonesian waters (Allen 1999, 11). Spatially, not all of the potential coastal area can be utilized for aquaculture. Therefore, according to Lumban-Gaol et al. (2018), the coastline and coastal areas should get attention from the government to develop the fishery of coastal areas and small islands.

With such a wide and extensive scope, the Indonesian maritime definitely possess diverse potential marine resources, both biological and non-biological. In addition to that, the majority of Indonesian people depend their living from the sea, by utilizing local genius, way of living, and household economic dependency from generation to generation to utilize marine resources to meet their daily lives. The vast marine area with a total of 17.840 islands, certainly provides an enormous value for the natural resources such as fish and coral reefs with biological richness with high economic value.

Unfortunately, the Indonesian paradigm regarding the sea tends to be different from the actual reality. The sea is viewed as a pool of waste due to disposal of industrial waste, household waste and agricultural waste to the sea, as if the sea is a waste disposal. Not only waste, but misuse of toxic chemicals, bombs, and tiger trawl may damage the marine biota and coral reefs. This condition needs to be highlighted by the government as well as practitioner, humanist, scientist, including historian and all society elements who focus on maritime field. Ironically, given that around 75 percent of this 
country consists of waters with thousands of island spreading from Sabang to Merauke, and from Rote to Sangir Talaut, until now it has not been well-utilized by the government of Indonesia.

Human needs to realize that they do not preserve the environment. Not only destroying the livelihood of most Indonesian, this irresponsible activity can also cause disaster for humans themselves. Therefore, it is important to recognize the benefits of ecology for human life since an early age. Many environmental conservation projects have been done, including (1) Campaign on cleaning the beach by not throwing garbage at the sea; (2). Recycling the industrial and factory waste before discharging it into water, sea and air; (3) Prohibition to damage coral reefs as a habitat for various marine life; (4) Prohibition to break some parts of the coral as a souvenir or building materials; (5) Prohibition to do illegal fishing; (6) Prohibition to use fish bomb, poison and trawl in fishing; (7) Reducing soil, water, and air pollution; (8) Campaign on mangrove action projects.

The direction of development policy since the independence of Indonesia is lacking of focus on the sea because it tends to emphasize on continental-based development, therefore the maritime sector becomes a peripheral sector. The maritime field which is defined as the sector of fishery, marine tourism, mining, maritime industry, sea transportation, building and maritime service, seem to be separated. There is no clear principal and where these sectors will be directed. The government of Indonesia should follow the examples of other archipelago states that are relatively smaller compared to Indonesia such as Japan, Korea, Thailand which comprehend their maritime potential well so they can proudly become developed countries since they utilize their maritime potential well and responsibly. That is why the Minister of Maritime Affairs and Fishery in the era of President Megawati Soekarnoputri, Rohkmin Dahuri, once emphasized that the demand of marine resources-based development must be made the top priority in developing the nation's economy, as quoted by Ralahalo $(2007,28)$.

Indonesia's marine wealth should be the primary sector in the development of national economy. Therefore, it is only appropriate if the government starts to direct the course of policies to maritime-based development. The point is, it is the time for Indonesian people to leave the tendency to look at the models of development in continental states such as the United States of America, China, Australia and many others. Some of the functions of the sea that should become the government's consideration in setting out maritime-based policies are; sea as a medium to unite the nation, transportation medium, resources medium, medium to establish social relation, medium of bio-ecology education, and medium of security defence. Identifying the values of maritime culture is a highly important aspect to reconstruct and lay the paradigm of the appropriate marine development to maintain the sustainability of the sea ecosystem in an integrated manner.

Therefore, Rochwulaningsih et al (2019) questions why Indonesia has not been able to become a great maritime state according to its economic opportunities through the availability of abundant natural resources, geographical conditions, and historical reality. They emphasized on the statement that if Indonesia intends to become a great maritime state, it is necessary to build strong maritime power in shipping, defence, and military.

In Indonesia, the maritime communities with maritime values created by their ancestors as a monumental cultural work, are inherited from generation to generation to meet the family needs as a beneficial life skill either for their living or maintaining the harmony of the sea environment including its content. They manage the resources collectively and live in harmony with the surrounding sea environment. The local wisdom of coastal community in managing the marine resources has always been integrated with the philosophy of life of the maritime community who uphold the principles of harmony, balance, and compatibility of relationship between human and the nature, as well as between human and the creator.

Unfortunately, many types of local wisdom of the coastal and small islands community have shifted; even currently, some of them are no longer being practiced at all. The values of maritime cultures which is the social normal that are intentionally inherited by the ancestors and are kept from generation to generation both in daily practices as well as in collective memory of the maritime community in Indonesia, now becomes weaker. As such, this writing aims to describe the shifting of local wisdom values of the maritime community in managing the marine resources in Indonesia by highlighting the issue of the weakening of local wisdom of the maritime community as the social 
capital in preserving and maintaining the marine environment as the source to meet daily needs of the maritime community.

The role and status of local wisdom as the law or regulation implemented in this coastal area is very important. Viewed from the historical perspective, it was obtained through a very long process and passed down orally by the community from generation to generation. From the point of view of its application in particular, it serves as a control over human nature whose needs and desires are endless, allowing the local wisdom to greatly affect the preservation of human environment as a place to live, especially in the coastal areas (Jumiarta et al. 2013,1). The potential local wisdom related to the preservation of marine environment for example is Petik Laut, a ritual carried out by the people in Gili Island by making a replica boat containing offerings in the form of tumpeng and cow's head, then it is floated on the sea accompanied by a fishing boat (Jumiarta et al. 2013, 1)

Another example regarding traditional ceremony to protect the sea is Jamu Laut or Pesta Jamu Laut that is generally found in the coastal communities of East Sumatra. It cannot be separated from the life of fishermen, especially in Jaring Halus village. Jamu Laut is performed on the request of Orang Laut. The visible signs are for example, the incidents where people fall into the sea, many fishermen get sick when they return from the sea, even some of them was in a trance (Tappil 2010).

The feebleness of traditional law and sacred rituals which govern the relationship between men and marine environment which should function as a form of protection of the people from the sea nature is getting weaker and is heading toward extinction. The feebleness of the function of local wisdom in maintaining balance and harmony of the surrounding nature, becomes a serious challenge that should be addressed prudently by the government, especially regarding the regulations which take side with local wisdom values of the coastal community and small islands.

The above condition is highly influential to the existence of the people's social governance, in an attempt to manage sustainable marine resources. As such, the existence of local wisdom values of the maritime community spreading across the Indonesian Archipelago must be maintained in order to preserve the balance between men and its marine environment. Revitalization is required on various local wisdom which is related with the maritime world in the homeland in order to keep performing its function well. In relation to that, it is relatable to quote from Dahuri (2016) that if we carry out the development of marine in an integrated manner, then a number of problems can be solved. In this regard, unemployment and poverty, disparity of development among regions, frailness of food and energy sovereignty, can also be addressed (Dahuri, 2016). The above-mentioned background proposes a new question on how effective the local wisdom values can be understood by the community so that it becomes the integral parts to internalize and to implement the preservation of the local community.

\section{Understanding Local Values of the Coastal Community: Some Rituals and Traditions}

In Law No. 322009 Chapter I Article 1 Paragraph 30, the definition of local wisdom is the prevailing values of ancestors in the order of life of the community are to, among others, protect and maintain the natural environment sustainably. This definition is made as one of the regulations in preserving the sustainability of natural environment on the protection and management of natural environment. The local wisdom is defined as a perspective of life and knowledge as well as various strategy of lives in the form of activities carried out by a local community in answering numerous problems in meeting their needs. In other language, local wisdom is often conceptualized as a local policy or local knowledge or local genius.

This definition is close to the existing culture in certain area, including in Indonesia with its diverse culture. Therefore, Indonesia is often called as a multicultural nation. Knowledge and experience of the people, according to Sunaryo and Joshi $(2003,38)$ is a custom which merge with the norm system, belief, togetherness, and equity expressed as the community tradition as a result of abstraction and interaction with the surrounding nature or environment in a very long period of time. Therefore, local wisdom becomes a guide in behaving and acting to meet the necessities of the people's daily lives. Local wisdom as a social capital is essential in maintaining the marine resources. The local wisdom for coastal community have two main roles, that is to meet the needs of marine resources to live and to survive the continuity of the community, including to maintain a harmonious relationship 
between people with the natural resources in their surrounding environment. Local wisdom covers five social dimensions: (1) local genius; (2) local culture; (3) local skill; (4) local resources; and (5) local social process (Apriyanto et al. 2008, 38). From the aforementioned five social dimensions, it illustrates that local wisdom also functions as the order of the people in keeping a harmonious relationship with their surrounding natural resources and environment.

This harmonious relationship results in the protection of the function of natural resources and environmental balance to achieve a sustainable management. Such relationship is connected with several value systems within the local wisdom, such as sanctification, taboo, restriction such as Sasi, which has various patterns. In addition to sanctification, Sasi, and taboo, there is a taboo that has a meaning as a 'rule' and 'restriction' for the people to do something that may disturb or damage the sea or a certain area.

Therefore, in order to maintain the sustainability of such resources, signs or restrictions of exploitation should be designed and implemented, adjusted with the existence of resources, zoning and characteristics of the resources as well as the characteristics of the region (province/regency/city) as a unit in the area being developed. In this case, as the implication of resources utilization conducted by the coastal community, it should be understood how the true characteristics of the coastal people are, so the policies, strategies and resource management program can accommodate the characteristics of the coastal community which is dynamic and very dependent on the availability of the surrounding coastal and maritime resources.

In relation with the characteristics of coastal community, Amri et al. $(2002,35)$ emphasizes that the coastal community is the community residing in the land by the sea who uniquely spend most of their lives above the sea water. In this understanding, the sea people such as those in Riau Island, Bajo people living in the east of Sulawesi, the people of small islands in Maluku such as Aru, Key, Ambon, Manipa, Kelang, Buano, Buru, Banda Gorom, Teor Islands and others, are also classified as the coastal social environment. The people who inhabit the islands of Raja Ampat in West Papua are also classified in the category of coastal and small island community in Indonesia. For the coastal and small island community, the dependency of their lives on the land natural resources is as much as their dependency to the water resources, even though it is greater to the sea. For example, culturally, the Bajo people are still considered a simple community and live according to the governance of marine environment, and they are known as the sea gypsies, who is living with the livelihood that is closely related with the sea, as well as possess knowledge and skill of fishing in the sea (Sulaiman 2005, 1-2). It is similar with the people of Maluku, North Maluku, and Papua who populate small islands and coastal areas who normally make the sea as an inseparable part of their lives. As such, the types of local wisdom of the community in coastal areas and small islands grow and develop with the product of marine culture as the answer and challenge for the surrounding natural environment.

There are many rituals or traditions that have been existed among the marine community. This section discusses of each rituals. (1) Bapongka, a tradition of Bajo tribe living in the coastal area of Bongganan Village, Banggai Island Regency, Central Sulawesi Province. This community always attempts to save the ecosystem and the surrounding coastal and marine resources by implementing their local wisdom called as "Bapongka". Bapongka is an activity to utilize marine resources as well as an activity to protect the exploitation of marine products in a certain time period. Bapongka is often considered as an element of marine and coastal resources exploitation with sustainability purposes (Alwiah \& Utina 2007, 107); (2) Sasi Laut in Aru Island is practiced by the majority of the people who populate few small islands and big islands such as in Tarangan island and etc. Sasi Laut functions to preserve the sustainability of the lives of marine resources in order to maintain its balance, including to control the pattern of resources under the sea so that they are not exploited excessively. Sasi in Aru Island is primarily to sustain the continuity of marine biota including pearl, which are often exploited enormously by the locals as well as by new comers outside the area. "Sasi" is one of the type of customs meaning to arrange the management and utilization of earth products both in the forest and in the sea. Sasi is the restriction used to organize the people in extracting the earth's product such as plants, as well as marine products and also to mark an area (Warawarin et al. 2017, 1-2). (3). Kei people living in small islands which stretch-out in South East Maluku have a custom to preserve the sustainability of their marine resources by exercising restriction against excessive exploitation on the 
resources both land and marine, widely known as "Hawear Balwirin", as provided in article 7 of the traditional law of Larwul Ngabal, the highest traditional law in Kei Island (Warawarin et al. 2017, 12).

Hawear is a traditional rule that applies in general for the people in Kei Island, and it has a binding characteristic toward the community from generation to generation. Usually, Hawear runs for several years, then it is opened for the public in general based on mutual agreement between the community and the village government. Hawear is similar to Sasi in Central Maluku which functions to maintain the balance between the needs of people with the availability of marine resources in each country that is spread in the Island. According to Lizza Laelatul in her writing "Menjaga Alam Seriby Pulau", the dilemma of traditional system of Sasi and the government's power in preserving the natural resources of Maluku Islands, describes that in Kei Island, Sasi has other names, that are Hawear, Yot in Big Kei islands, and Yutut di Small Kei islands (both are performed by involving a few relatives or certain communities) and the smallest is Mitu (its performance encompasses several families) (Zaen 2016, 2).

Hawear, Yutut, Yot, and Mitu, are the form of local wisdom in Kei Island to maintain the sustainability of natural products as well as the harmony between nature and human. Various local wisdom to sustain the marine nature in Maluku are supported by the area of Maluku Island which is called thousand islands, as geographically, Maluku has a total of 812 islands comprising of small islands with a total sea area of $92.4 \%$ and land area of $7.5 \%$ of the total area of Maluku. From the total area, the water area of Maluku is about 12 times its land area (Nendissa 2010, 1). (5) Sasi or restriction also exists in West Papua, particularly in the community that inhabit the small islands in Raja Ampat, and Misol. Sasi in both Raja Ampat and Misol, is under the sea conservation territory of Raja Ampat area which is directly handled by the regency government, Fishery and Maritime Office, together with International NGO such as the Conservation International and the Nature Conservation. These organizations revitalize the tradition of sasi in numerous communities of traditional people in their working territory, that has experienced a cultural shift due to the demand to meet the society's lives and the weakness of the sasi institution itself. The marine conservation they uphold, internalizes sasi into the conservation territory zone which they develop together with the regional government initiated by the Maritime and Fishery Office. The zone of sasi becomes the zone of traditional utilization, even in the Conservation Territory of Kaimana water, the zone of sasi becomes an exclusive feature zonation, fish deposit zone or fixed zone of sasi, which become a zonation of tradition protection, managed and run in a participatory manner (Muljadi et al. 2006, 10).

Sasi is performed in the district of West Misol, although it does not recognize written and standard rules in its implementation, yet the people already know and comprehend the rules of the tradition especially those related to the performance of closing and opening of the implemented sasi. The above opinion is supported by Eva Lestari and Arif Satria in their writing regarding; Peran Sistem Sasi Dalam Menunjang Pengelolaan Berkelanjutan Pada Kawasan Konservasi Perairan Daerah Raja Ampat, which describes that the people who inhabit the sasi-ed surrounding water zone is only permitted to pass in that area and is not allowed to take marine biota such as; lola, lobster, sea cucumber, and fish in the zone of Sasi, because the restriction is effective upon the execution of sasi closing ceremony (Lestari \& Satria 2015, 67).

Vetrau, similar to Sasi, also presents in Sobey Tribe in Kampung Sawar, West Irian with the local community practicing it to maintain the conservation of nature such as coral reef, sharks, dolphins, sea mammals and turtles. The meaning of Vetraw in Sobey Tribe language contains the meaning of restriction for the marine area and restriction for the land area. Vetraw or restriction which exist in Sarmi Regency, Papua Province, especially in the Sobey tribe and including the tribes inhibiting the coastal area, have a similar meaning and system to protect and preserve the surrounding natural resources. Sasi in Central Maluku is also practiced by the people who inhabit the small islands as well as big islands in the province known as the thousand islands. In North Maluku, such as the population of Halmahera, Ternate, Tidore, Bacan, Jailolo, and Obi also know the same sasi as that which exist in Central Maluku especially the people of Buru, Seram, Ambon Kep Lease, Watubela Banda, South West Maluku Island, and Island of Tanimbar. The people in the places as mentioned above, considered restriction in the form of sasior other names as the restriction and is also considered "taboo", or 'pamali'. It is believed that if someone carries out exploiting activities on the restricted 
natural resources based on the mutually agreed traditional vow and promise, then he will be subjected to traditional punishment according to the prevailing traditional law in that area. With such sasi or restriction above, then the marine resources and ecosystem in the zone of sasi will remain preserved.

Implicitly, such places become an area of 'conservation', however today, with the advanced technology as well as increase in the needs of human's lives as the population grow in number, the values of local wisdom of the maritime community is going weaker. The consequence is a disorder when exploiting marine resources, resulting in the increasing social conflicts between the coastal and small island communities in the motherland of Indonesia since the traditional rules which provide the values of local wisdom are no longer respected by its supporting community. If such condition is not managed properly, it certainly will lead to new social issues related to the social conflict among fishermen living in the small islands and coastal areas.

\section{Traditional Values Preservation vs Excessive Exploitation: Local Responses on Environmental Problems}

Unfortunately, today, the cultural values related to such maritime is being left out by its supporting community. A case in Maluku, for instance, with the rapid growth of population due to the increase of migrants from the Island of Buton since the declaration of independence until today who generally inhabit the majority of coastal and small islands area in Central Maluku, causes the exploitation of marine resources to be more difficult to address.

Such case above, is also mentioned by Novaczek, et al. (2001) that the destruction of marine environment especially in small islands spread across Central Maluku is caused by an unlimited exploitation of marine resources by the newcomers from the Island of Buton who do not share a connection with the structure of traditional power of the villages in Maluku, hence they often do not comply with the sasi or traditional restriction set out by the locals (Novaczek 2001). What is said by Iren Novaczek et al., in that writing can be justified because until today, the newcomers from the Island of Boton generally occupy the majority of small islands such as the Osi Island, Kelang Island, Kasuari Island, part of Buano Island, and Western Seram Coastal Islands. They depend their economic lives by utilizing the surrounding marine resources.

As such, it cannot be denied that in order to meet their daily needs, they have to exploit the available marine resources to meet the economic needs of the family. However, what is unfortunate is the practice of using bombs and chemicals such as potassium illegally to catch a huge number of fish. They also exploit the living coral reef to be sold to dealers with an enticing price. Such illegal practices should not happen and cannot be ignored; it should be handled in an integrated manner by the village government, in this case is the traditional institution that functions in organizing the implementation of traditional rules, and it needs an attention from the regency government as well as the province, so the newcomers have to participate in maintaining the sustainability of marine resources. Its management must be performed through socialization about sasi or traditional restriction to the newcomers, and enforcement of regulations such as punishment in accordance with the applicable positive law so that the sasi or traditional restriction is truly complied by all people without exception.

It is true that in the current era of regional autonomy, there is a tendency of regional government seeking short term interest by prioritizing the projects of people empowerment in the field of fishery which often contradicts with the traditional interest that sets the governance of natural resources particularly marine products, traditionally. On the other hand, the existence of fishermen organization or other empowerment group set out by the regency government is increasing, while the governance of fishery that is environmentally friendly and referring to local wisdom in the area, is never established by neither regency nor provincial government. On the other hand, the attempt to improve the people's economy in the long term through empowerment of fishermen community is very important in anticipating poverty. Therefore, the empowerment of the people of small islands and coastal area should not only be directed to the enhancement of fishermen's household economy security, but also should be accompanied by the social cultural aspect, especially related to the pattern of environment preservation. 
The role of government is needed to exercise an update of knowledge and attitude of the fishermen in connection with the knowledge and skill to protect the marine ecosystem by doing socialization to the fishermen community about the function of local wisdom as a tradition that should be complied. As suggested by Zamzami $(2016,57)$ through the government's program such as coastal community economic empowerment program (PEMP), the cultural value (tradition) and religion form should always be regarded through a role of an institution that is growing and developing in the local community; hence the existing program is expected to be able to increase the participation of the people in decision making and supervision of the management of marine resources and coastal area. Therefore, the local wisdom in organizing the marine resources, ideally needs to be preserved through various direct practice as well as socialization to the people. Indeed, as the development and course of time, the local wisdom, especially those related with maritime, gets more and more challenging, and it also affects its existence.

The condition above is caused by many factors, especially those related with the pressure of the population on the surrounding marine resources and nature as well as the development activities, and modernization due to direct impact of globalization effects. The effects of globalization can also lead to extravagance in natural resources, increase in the usage of chemicals such as potassium, bombs, and the emergence of numerous issues due to the advancement of modern technology that is misused by the people. In addition to the impact in economy, globalization also affects the social and culture of the people such as the weakening of local wisdom which is associated with the protection of marine resources today. Globalization has driven the shift or change in the system or rule which grows and develops in the local community from generation to generation. The consequence is the exploitation of marine resources without considering at the physical growth of the marine ecosystem such as fish, coral reef, sea cucumber, and many others. The growth of marine biota is greatly influenced by the physical environment of nearby water. Thus, the natural environment under the sea must always be preserved well.

Ecologically, the factors which influence the distribution (dispersion) of growth and diversity of the coral reef ecosystem are highly dependent on the physical, chemical and biological conditions of the water (environment) in which the condition often changes due to the disturbance of human activities directly or indirectly. The factors are light, temperature, salinity and sedimentation (Leiwakabessy 2016, 91). There are several factors that cause the damage of coral reef, they are: (1) mining of coral reef for building materials, road, and decorations; (2) catching fish using explosives, poison and certain fish catching equipment that cause damages; (3) water pollution from industrial, agricultural and household waste; (4) sedimentation and increase of murkiness in the water due to land erosion in the shore, excavation and mining; (5) excessive exploitation of fish and coral resources. The ecosystem of seagrass, in particular, is vulnerable to the degradation of environment due to human activities. Some human activities that can damage the seagrass ecosystem are dredging for the development of seashore residence, port, industry and navigation channel, pollution of industrial metal especially heavy metals, and organochlorine compound, organic waste disposal, pollution by industrial waste, agriculture, and oil.

In addition to natural processes, such as wind, flow, rain and wave, human activities also contribute to the primary factor of beach erosion. Human activities that cause beach erosion is opening of mangrove forest for residence, building infrastructure and pond fisheries, that much decreases the protective function for the beach. In addition to that, the coral reef mining in numerous location for road and building construction has given an important impact on beach erosion, for the decrease or loss of beach protection against ocean waves and storm (Bengen 2009, 36). Several issues of natural environment above are challenges that need to be faced together by all society elements in Indonesian that currently is experiencing a great natural environment issue.

In addition, there are some fishery resources that have been exploited excessively (overfishing), including prawn, demersal fish, small pelagic and reef fish. It happens primarily in regions with dense population, such as in gulf of Malaka, northern coast of Java Island, Gulf of Bali, and South Sulawesi. The diminishing of the resources, in addition to overfishing, is also caused by economic activities that lack of calculating the availability of marine resources, hence damaging the ecosystem and environment. In addition to that, it is caused by the poor appreciation and knowledge to carry out conservation of fishery resources, such as prawn, mangrove, coral reef, and others. To address this 
excessive exploitation of marine as well as land resources, several territories in Indonesia has implemented a restriction system, such as Sasi in Maluku, and Papua. Currently, Sasi tends to be a rule of traditional law in nature that is applicable and exercised from generation to generation. Sasi is generally applicable in the community as a form of traditional ethic and considered as a traditional rule to prevent excessive exploitation of resources.

There are three important things contained in the restriction or sasi that can be made as patterns to prevent excessive exploitation, that are: 1) Restriction to utilize the resources within a certain time period to allow organism regeneration in order to maintain the level of population of each organism in the surrounding nature. 2) Violation on the restriction that has been enacted and bound under the traditional law, shall be imposed a traditional punishment according to the applicable custom for such community.

In general, the traditional maritime communities make the social institutions as a set of integrated rules with organization/institution that regulate certain activities and is functioned as a mechanism of self-adaptation to the environment or resolution of urgent social economic issues. Some of the examples of economic institution of the maritime community are institution of cooperation and institution of right to utilize marine resources. In Indonesia, various types of control/ownership right of area and marine resources are found in some places, such as in Central Maluku. This institution of communal ownership over a land and beach area is organized by "Kewang" institution which regulate about land and Marine Sasi. Kewang institution is one of the traditional administratives that adheres to the system of traditional government in Maluku, particularly in Central Maluku. Kewang Institution functions to carry out the ceremony of Marine Sasi as well as sasi on land over various resources products that is deemed necessary to be preserved. The ritual used in the sasi ceremony is usually performed by uttering sacred sentences and is binding human and their Creator who guards and protects the universe, hence the compliance of the people toward sasi or restriction is solemnly kept and not violated.

The compliance of the people to sasi is the proof of respect to customs which is an inseparable part from the cultural practice, especially the teaching of local religion that is connected with three things; (1) Related with religious belief or religious emotion. (2) Related with human attitude toward supernatural universe. (3) Related with religious ceremony (Koentjaraningrat 1981, 58). All three things above are influenced by the culture practiced by its people. Organization or institution such as Kewang Institution in Maluku, is included in the three categories mentioned above; therefore, the institution remains preserved in some villages, particularly in Central Maluku. Whereas in Kei Island and Aru Island, Sasi is normally entrusted to the village government. Unfortunately, currently the function of Kewang Institution is getting weaker in the aspect of traditional rules due to the intervention of the church that oversees the execution of sasi in the manners acceptable by the church. While in fact, sasi is a cultural institution which is related to the traditional law in Maluku.

Current phenomena mentioned above is supported by the view of Nikijuluw (1998) that sasi (traditional practices which limit access to the area and or resources) is organized by traditional leaders, but it is informal. Sasi in an area means to prohibit outsiders from coming in and doing a particular behavior for a certain period of time. The village head usually serves as the direct organization leader of the sasi activity. He is assissted by kewang (traditional village police) to represent the locals in performing and enforcing the sasi. Kewang consists of a leader and several members. The church also oversees sasi for a certain period of time in a year whether related to the forest product as well as sea product and is limited in nature because it is only applicable for the Christian community.

The church which runs the sasi is usually led by the church leaders or pastors, but it is not enforced with supervision or punishment. However, until today, Sasi is still organized by the church in some villages in which the community are Christians. There are lots of violation cases that is very minimum and in the event of such cases, they are usually conducted by outsiders or new comers. The presence of Church organization locally, allows the traditional local institution to replace the role of government and province in managing the coastal fishery resources (Nikijuluw 1998, 40).

Referring to the explanation made by Nikijuluw concerning the roles of the Church in the implementation of Sasi in Maluku, it is actually an effort to divert the function and role of Kewang Institution that has run very long since the Dutch colonialism, that is not given any space to arrange and to be responsible of the rules of traditional law applicable for the local people where the traditional 
government organization or traditional institution grows and develops. In the era of independence, whether in the old order as well as new order, similar condition is also experienced as happened during the colonialism period because of the implementation of centralized system turned out not providing any space for the development of traditional governmental system which structurally contains the function and roles of Kewang to organize the governance of natural environment nearby the local population residence.

To answer several environmental problems in Indonesia, in the 1980s, some conservatory areas were established by the government, such as Bonaken sea garden, Takabonerate, P. Seribu and in Maluku such as Pombo Island, Island of Lusipara, and Tuju Island, north of Seram Island. In Irian, several islands that are currently considered potential have been made as tourism destinationa such as Raja Ampat, Misol, and many more. In each conservatory area, especially those located in reef area such as small islands, a sanctuary zone is implemented, as well as buffer, utilization of traditional equipment, and intensive utilization outside the area. This control over the country is intended to save the marine ecosystem, particularly marine biota, coral reef and other sea habitat in which the primary species are starting to be threatened.

In South Sulawesi, several non-governmental organizations with a paradigm that sides with the interest of the people bear underlying vision and mission in improving the socio-economic welfare, improving human resources, improving people's skill, nourishing the spirit of democracy, and sustainability of social and culture, as ewell as physical environment. Usually, they combine their knowledge with the local community, especially the local high education institutions. The research performed by Effendi et al. $(2014,151)$ presents an interesting explanation concerning the implementation of Conservation Village Model (MDK) as a pilot project of community empowerment in the surrounding natural conservation area runs by the government through the Directorate General of Forest Protection and Natural Conservation (PHKA) since 2006.

Similar conservation model can also be found in Bengkulu city with the pattern of CoManagement, which is a collaboration of fishery management by the distribution of responsibilities and rights between the government and local people in managing the fishery resources. Based on the definition of Co-Management, then the government and the people are collectively responsible in doing all stages of fishery management. In relation to Co-Management as explained by Alains et al. $(2009,172)$ refers to the patron-client relationship is still dominating the area and also the economy in the form of social security for the fishermen. The fishermen community in such area generally have a kinship relationship between one village and another, and their participation in supporting the government in maintaining and preserving of the marine ecology collectively. The fishermen's strategy to survive is still considered traditional and affected the pattern of fishery resources management in a traditional manner as well.

\section{Conclusion}

In order for the sustainability of coastal and marine environment and ecosystem is preserved, the value of local wisdom needs to be reviewed and implemented for the supporting community so that it can be maintained as a superior cultural practice that is beneficial for the human lives, especially in maintaining the sustainability and balance betwen men and nature. To maintain the values of local wisdom that are related to the community in the coastal areas and small islands in preserving the marine ecosystem as described above, several conclusions have been made. Even though, all this time, the maritime culture of fishermen communities in Indonesia has not received much attention from the government, it is shown a dynamic process which occurs pretty rapidly everywhere. Without underestimating, a few local wisdoms are still enacted even though they are getting weaker, for example "Sasi" (Maluku), Bapongka (Sulawesi), Vetrau (Papua), Hawear, Yutut, Yut, and Mitu (Kei Island). 2) Kewang Institution in Maluku and Panglima Laot reflects on co-management of cooperation institution of marine resources which keep existing despite the challenges of the modern technology. Meanwhile, the involvement of local community is essential to preserve marine and coastal ecosystem.

In addition, communities living in the coastal areas such as in Central Maluku, Kei Island, Aru Island, West Papua, Banggai Island, and Northern Coast of Java, traditionally have conducted efforts 
in the form of rituals and tradition of the coastal and marine ecosystem passed down through generations. The people of Maluku and Papua have preserved marine environment by performing several rituals such as sasi to keep a harmonious life between human and their surrounding environment. Last but not least, the government should participate in establishing a development system to reduce disparity.

\section{References}

Alains, Muluk, Sepriati Eka Putri, and Perilia Haliawan. 2009. "Pengelolaan Sumberdaya Perikanan Berbasis Masyarakat (PSPBM) Melalui Model Co-Management Perikanan.” Jurnal Ekonomi Pembangunan 10 (2): 172-198.

Allen, Gerald R. 1999. Marine Fishes of South-East Asia: A Field Guide for Anglers and Divers. Clarendon: Tuttle Publishing.

Alwiah, A. \& Ramli Utina. 2008. "Bapongka: Studi Nilai Pendidikan Pelestarian Ekosistem Laut dan Pesisir Pada Masyarakat Bajo.” Jurnal Matsains 12 (1): 108-120.

Amri, Marzali. 2002. Pengelolaan Lingkungan Sosial. Jakarta: Yayasan Obor.

Apriyanto, Y, I. Pardede, I, \& E. R. Fernando. 2008. Kearifan Lokal Dalam Mewujudkan Sumber Daya Air yang Berkelanjutan. Bogor: Institute Pertanian Bogor.

Bengen, Dietriech G. 2009. Sinopsis Ekosistem dan Sumber Daya Alam Pesisir dan Laut. Bogor: Pusat Kajian Sumber Daya Pesisir dan Lautan Institut Pertanian Bogor.

Effendi, A. Dani, Rolan A. Berkey, \& Muh Hata Jamil. 2014. Strategi Pengembangan Program Pemberdayaan Masyarakat Pada Model Desa Konservasi di Taman Nasional Taka Bonerate. Jurnal Sasi and Teknologi 14 (2): 151-161.

Fredy. Leiwakabessy. 2016. Struktur Komunitas Gastropoda di Zona Pasang Surut Pulau Ambon. Jakarta: Polimedia Publising.

Koentjaraningrat. 1980. Pengantar Ilmu Antropologi. Aksara Baru. Jakarta.

Lestari, Eva \& Arif Satria. "Peran Sistem Sasi Dalam Menjaga Pengelolaan Berkelanjutan Pada Kawasan Konsevasi Perairan Daerah Raja Ampat." Buletin Ilmiah "Marina” Sosek Kelautan dan Perikanan 1 (2): 67-76.

Lumban-Gaol, J., N. Natih, \& M. Yulianto (2018). Kajian Lahan Potensial untuk Budidaya Perikanan dari Citra Satelit di Pantai Timur Belitung. Majalah Geografi Indonesia 32 (2): 207-215. DOI: http://dx.doi.org/10.22146/mgi.33420

Muljadi, Andreas H., Titi Nugraheni, Gede R. Wiadnya, M. Barmawi \& Peter J. Mous. "Laporan Pengamatan Insidental di Kofiau, Raja Ampat.” Protokol Monitoring Versi 1.0, Juni 2006. The Nature Conservancy - Coral Triangle Center (TNC-CTC) Kofiau, Raja Ampat.

Nendissa, Reny H. 2010. "Eksistensi Lembaga adat dalam Pelaksanaan Hukum Marine Sasi di Central Maluku”. Jurnal Sasi 16 (4): 1-6

Nikijuluw Victor. 1998. "Identification Indegenous Coastal Fiseries Management (ICFM) Sistem In Sulawesi, Maluku end Irianjaya." Jurnal Pesisir dan Lautan: Indonesian Journal of Coastal of Marine Resources 1 (2): 40-56.

Novaczek, I. Ansye Sopacua, and Max Tatuhey. 2001. Marine Sasi In Maluku, Indonesia. Published by ICLARM-The World Fish Center. Penang Malaysia.

Ralahalo, Karel Albert. 2007. Pembangunan Daerah Kepulauan dan Visi Maluku 2030; Menjadikan Maluku Sebagai Daerah Industri Berbasis Sumberdaya Kelautan Paling Kompetitif di Indonesia. Jakarta: PT. Bintang Ilmu.

Sulaiman, Maman. 2005. Kebudayaan Masyarakat Maritim. Palu: Universitas Tadulako Press.

Sulistiyono, Singgih T. 2017. "Tracking the Role of Education in Preserving National Indentity: Maritime Aspects in the History Subject at Senior High School in Indonesia." Journal of Maritime Studies and National Integration 1 (1): 55-65. DOI: https://doi.org/10.14710/jmsni.v1i1.1373

Sunaryo D. \& L. Joshi. 2003. "Peran Knowledge Ekologi Lokal dalam Agroforestri." https://www.worldagroforestry.org/publication/peranan-pengetahuan-ekologi-lokal-dalamsistem-agroforestri 
Tappil, Rambe. 2010. "Upacara Jamu Laut (Studi terhadap Masyarakat Melayu Nelayan di Desa Jaring Halus Pulau Beting Kecamatan Secanggang Kabupaten Langkat Sumatera Utara).” http://digilib.unimed.ac.id/3216/. Accessed December 20, 2020.

Warawarin, Casparina Yulita, Hafid Cangara, \& Muhadar. 2017. "Makna Kominikasi Simbolik Hukum Adat Sasi Dalam Pelestraian Alam Laut di Kabupaten Maluku Tenggara." Jurnal Komunikasi Kareba 6 (1): 1-19. DOI: https://doi.org/10.31947/kjik.v6i1.5136

Zaen, L. L. Izzah. n.d. "Menjaga Alam Seribu Pulau.", https://www.academia.edu/6439644/Menjaga_Alam_Seribu_Pulau. Accessed December 1, 2020.

Zamzami, Luki. 2016. "Dinamika Pranata Sosial terhadap Local wisdom Masyarakat Nelayan Dalam Melestraikan Wisata Bahari.” Jurnal Antrpologi-Isu-Isu Sosial Budaya 18 (1): 57-67. 